\title{
The Perspectives to Understand Social Marketing as an Approach in Influencing Consumer Behavior for Good
}

\author{
Iin Mayasari \\ Universitas Paramadina, Jakarta, Indonesia
}

\begin{abstract}
This study is a conceptual paper and highlights perspectives to understand social marketing as an approach to bring about voluntary and socially desirable consumer behavior. The perspective is considered as an alternative way to comprehend consumer behavior change for good as a multi-factor driven action. Hence, social marketing is also considered as a discipline that can be analyzed from multiple perspectives including a behavioral change perspective and a relationship perspective. Each perspective is elaborated by doing a review of existing literature and research. This study shows that social marketing is not only the application of marketing programs to shape consumer behavior, but also a process involving individual, society, and government to make a better life of society.

Abstrak: Studi ini merupakan studi konseptual dan memfokuskan perspektif holistik untuk memahami pemasaran sosial sebagai pendekatan dalam menciptakan perilaku konsumen yang secara sosial dianggap ideal. Perspektif ini dipertimbangkan sebagai cara alternatif untuk memahami perubahan perilaku konsumen sebagai sebuah tindakan yang dipengaruhi oleh keragaman faktor. Seiring dengan hal tersebut, pemasaran sosial juga dianggap sebagai sebuah disiplin yang dianalisis dari keragaman perspektif, yaitu perspektif perubahan keperilakuan dan perspektif hubungan (relasi). Masing-masing perspektif dianalisis dengan menggunakan tinjauan literatur dan penelitian terdahulu. Studi ini menunjukkan bahwa pemasaran sosial tidak hanya merupakan penerapan program pemasaran, namun juga proses yang melibatkan individu sendiri, masyarakat, dan pemerintah untuk terciptanya kehidupan bermasyarakat lebih baik.
\end{abstract}

Keywords: behavioral change perspective; relationship perspective; social marketing 


\section{Introduction}

The social marketing concept has been discussed since Kotler and Zaltman initiated it as an approach to planning social change in 1971. Social marketing has been the alternative way to overcome the negative impact of sales orientation as a marketing approach (Kotler and Zaltman 1971). Kotler and Zaltman (1971) defined social marketing as the design, implementation, and control of programs calculated to influence the acceptability of social ideas, and involving considerations of product planning, pricing, communication, distribution and marketing research. Meanwhile, Lefebvre (2011) also defined social marketing as the application of marketing principles to shape markets that are more effective, sustainable and just in advancing people's well-being and social welfare. Marketing social is not for the achievement for profit, but the primary motivation is only for enhancement of public good (Donovan 2011).

The orientation for gaining high profitability has pursued the corporation in commercial sectors to reach financial gain. Corporate marketing strategy encourages consumers to consume more of the product offered by aggressive selling and great promotions. Consumers have been offered abundant products and services, consequently consumers do not have much sovereignty to defend. All this has created social problems for consumers, such as health problems. Health problems can weaken consumers' ability as members of society to be more productive.
Marketing should have been directed at society and marketing principles and strategies used to engender social good and avoid negative consequences (Hastings 2007). Marketing has the ability to create consumer well-being by offering consumers with goods and services that preserve and enhance consumers' quality of life including the public dimension and the environment (Sirgy and Lee 2008). All commercial corporations can implement social marketing, but the tobacco and alcohol industries cannot because it is only for corporate reputation (Hastings and Angus 2011). Previous research showed that there are some strategies to ensure the protection of consumers, especially children, from commercialization of daily life (Klein 2000); commercialization by big pharmaceutical companies, (Blech 2006; Conrad 2007); the bombardment by the fast food and soft drink beverage industries (Molnar 2005); dominated by media interests and liquor marketers; and the commercialization of children by clothing, fashion and other marketers (McLaughlin 2009). Social marketing is believed to be able to promote public health and community and to influence consumers to engage in healthy behavior.

In the development of a marketing concept, social marketing is a specific part of marketing management that also tries to create, to distribute and to communicate values to customers as it is done in commercial marketing. Table 1 provides the comparison between social marketing and commercial marketing as the classic marketing. Social marketing and commercial marketing have the 
Gadjah MadaInternational Journal of Business -May-August, Vol. 14,No. 2, 2012

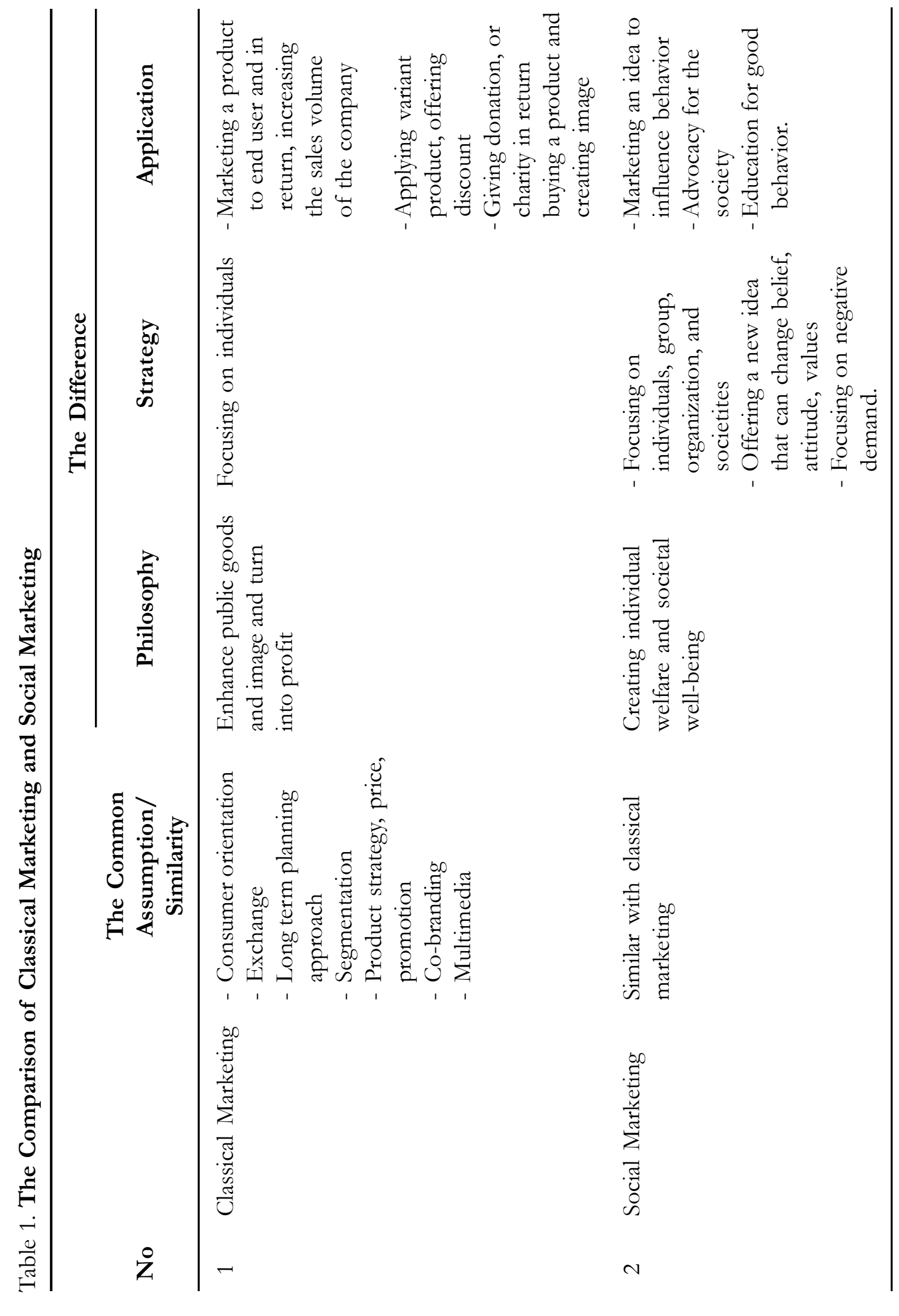


same philosophy and concepts: consumer orientation (Andreasen 1995); an exchangein social marketing, the exchange of goods not for the money but it can be in another form (Kotler and Zaltman 1971); long-term planning approach-marketing programs should have internal and external analysis (Andreasen 1996). The strategies to implement the social marketing are similar to the strategies implemented in commercial marketing or classical marketing such as the use of media, multi-channel, audience segmentation, co-branding, and develop product, price, distribution and communication strategies (Evans 2008).

Table 1 also describes the differences social marketing and commercial marketing. The most important philosophical difference of social marketing is that the programs are not undertaken for the markerter but the program will create long term individual welfare or societal well-being (Andreasen 1994). The motivation does not enhance the public good and turn the profit (Donovan 2011). Commercial marketing focuses on individual consumers while social marketers influence the behavior individuals, group, organization, and societies (Lawther and Lowry 1995; Lawther et al. 1997). MacFayden et al.(1999) provided the differences from commercial marketing it terms of the characteristics of product, demand, and consumer involvement. Products marketed in social marketing programs must be complex because they offer new ideas that can change beliefs, attitudes, values, and promote new behavior of doing new acts and sustained practices. Social marketing tends to deal with negative demand because it provides an idea that might create resistance to proposed behavior change. Social marketing only deals with high consumer involvement because it requires detailed factual information.
In addition, to understand the difference between social marketing and commercial marketing, it is important that social marketing has the important outcome. Lee and Kotler (2011) argued that healthy behavior as the outcome of social marketing can be in the form of: 1) accepting new behavior (e.g. stop smoking); 2) rejecting potentially undesirable behavior (e.g. start drinking): 3) modifying current behavior (e.g. increase physics activities; 4) abandoning an old undesirable behavior (e.g. talking on cell phone while driving). Furthermore, Lee and Kotler (2011) have listed major issues of social marketing that can impact consumer and society as a whole involving health related behavior (tobacco use, obesity, HIV/AIDS, cholesterol, cancer, diabetes); injury prevention related behavior (drinking and driving, seatbelt, school violence); environmental behaviors to impact (waste reduction, air pollution); community involvement behavior (organ donation, voting, literacy); and financial behavior (bankruptcy, fraud).

The complexity of social problems to be analyzed needs a wider perspective when discussed. This study provides an overview of behavioral change perspective and relationship perspective to understand social marketing as the alternative approaches to create good society and good individual behavior. Each perspective is elaborated with underlying theories and practices of social marketing. Hence, it can provide a framework that social marketing concept can be supported by various theories.

\section{The Need for the Perspectives}

Implementing social marketing for solving social problems needs comprehensive information to deal with them. The social problems are assumed to be complex and in- 
fluenced by norms and preferences. The correct solution to a social problem is based on the decision maker's understanding of the cause of the problem (Wymer 2011). The root problem is to intervene to turn the behavior into a new behavior or modified behavior that is socially desirable. The bad behavior has been habituated and very deeply ingrained in consumer's life. Therefore, it is very difficult to support the creation of healthy behavior.

The complete comprehension of the social problem is demanding because it cannot restrict the choice of strategies to targeted consumers. The framework acknowledges the presence of both internal and external factors to determine good consumer behavior. The focus on just one side will decrease the ability to support the behavior change. It needs multi perspective to understand socially desirable behavior. This study proposed two perspectives to portray socially desirable behavior as the aim of social marketing.

The two perspectives are behavioral change perspective and relationship perspective. These perspectives can make the understanding of the main discussion of social marketing more comprehensive. The wide perspective highlights the importance of finding solutions to social problems. The social problems are multi-dimensional. This wide perspective is in line with the unit analysis of social marketing. Social marketing has analysis levels from the micro level of the customer (Domegan 2007). The next level is the group level and the macro society level that consists of controlling the social context (Brenkert 2002). Each perspective has underlying reasons to be discussed as follows.

First, the behavioral change perspective is the initial lens to portray individual behavior change. Behavior change will be successful if it is mainly driven by individual aware- ness. The awareness for engaging in good conduct is significant for sustaining the success of behavior change. This perspective uses aspects of psychology including perception, motivation, attitude including cognitive and affective dimensions. The behavior change is easily manipulated if an individual consumer realizes the consequence of any action. Unhealthy behavior can change into healthy behavior by internalizing the values of good living.

Second, the behavioral change perspective is critical to explain the good behavior of consumers since it tries to change existing habits and routines that are persistent in individuals. Commonly, individuals find it very difficult to change to a new, more acceptable behavior because the primary reasons for people to stick on habit are influenced by the limited cognitive resources relating to change. Individuals use their minimal cognitive effort to require more thoughtful action (Verplanken and Aarts 1999). Furthermore, the modification of new behavior is impeded by the fear of breaking some interactions that is already imbedded (Dosi et al. 2008). The habit of bad behavior such as smoking or littering can be eliminated through self-reinforcing including seeking out information that confirms views, beliefs, and behavior for having good health for a better life. It starts from changing the way of thinking. This thinking is related to cognitive aspects and can lead to behavior change.

Third, in order to change the behavior of consumers into good socially acceptable behavior in society, focusing on behavioral change perspective is important. In addition, it can achieve the effectiveness of social marketing programs. Lee and Kotler (2011) summarized the importance of using the behavior perspective in social marketing pro- 
grams as follows 1) starting from individuals - the behavior can be formed by iniatiating a strong positive intention; 2) there are no environmental constraints that make it impossible to perform the behavior; the constraints lie in individual thinking, attitudes, perceptions, motivations or individual differences; 3) the individual itself can weigh up the benefit or disadvantage of promoting a good behavior; 4) the individual will have more pressure to perform the behavior than not to perform; 5) individual itself has the capability to perform the behavior; 6) the individual has the skill necessary to engage in the behavior; 7) the individual has emotional reaction to engage in the behavior.

Fourth, focusing on the behavior change perspective is relatively easy to be implemented because it also requires good coordination for formulating marketing strategy. Marketing strategy can be the tool for influencing behavior through communication programs. Andreasen (2002) argued that social marketing program targets behavior change through implementing programs such as segmentation, 4P-programs, and understanding the competition.

In addition to the behavior perspective, the relationship perspective is also important to explain social marketing programs (Raval et al. 2007). First, the relationship perspective discusses that social marketing does not only focus on individual behavior change, but it also extends to groups, organizations, and society (Lawther et al. 1997). Under some circumstances, to succeed in the implementation of social marketing programs, the change initiated by individuals does not work well and it is faces inertia. So, it needs good coordination and relationships with other actors to pursue the behavior change including government, organizations, and even pri- vate companies to cooperate in implementing social marketing programs.

Second, implementing the relationship perspective needs an awareness that creating good behavior is not only the responsibility of individuals. It needs the relationships with stakeholders of organizations including society, organizations, and government. This is the obligation of other stakeholders to pay attention to creating well-being for society. The relationship perspective also emphasizes the cooperation with stakeholders (Hastings 2003). According to Domegan (2008), social marketing stresses relationships beyond the consumer into the traditional market place, including suppliers, distributors, supporting firms, and extending to the broader social context of local communities, regional bodies, and government.

Therefore, coordinating and developing a program can entrench a network by involving society as the part of sustaining behavior. An individual consumer is a social person therefore the existence of social environment supports the formation of behavior. Behavior can easily be changeable if the influence of social environment is highly unavoidable. Government, for example, describes the upstream line to sustain the creation of healthy behavior. The relationship perspective is closely related to the government role by formulating policy that regulates aspects of support for healthy behavior. Regulation enforcement is expected to direct individuals, society, and commercial sectors to comply with the existing rules. This is a compulsory mechanism.

Third, the relationship perspective argues that the behavior formation does not occur in the short-term. Social marketing is not only an advertising campaign to inform people to do so or it is not about health pro- 
Gadjah MadaInternational Journal of Business - May-Aunust, Vol. 14,No. 2, 2012

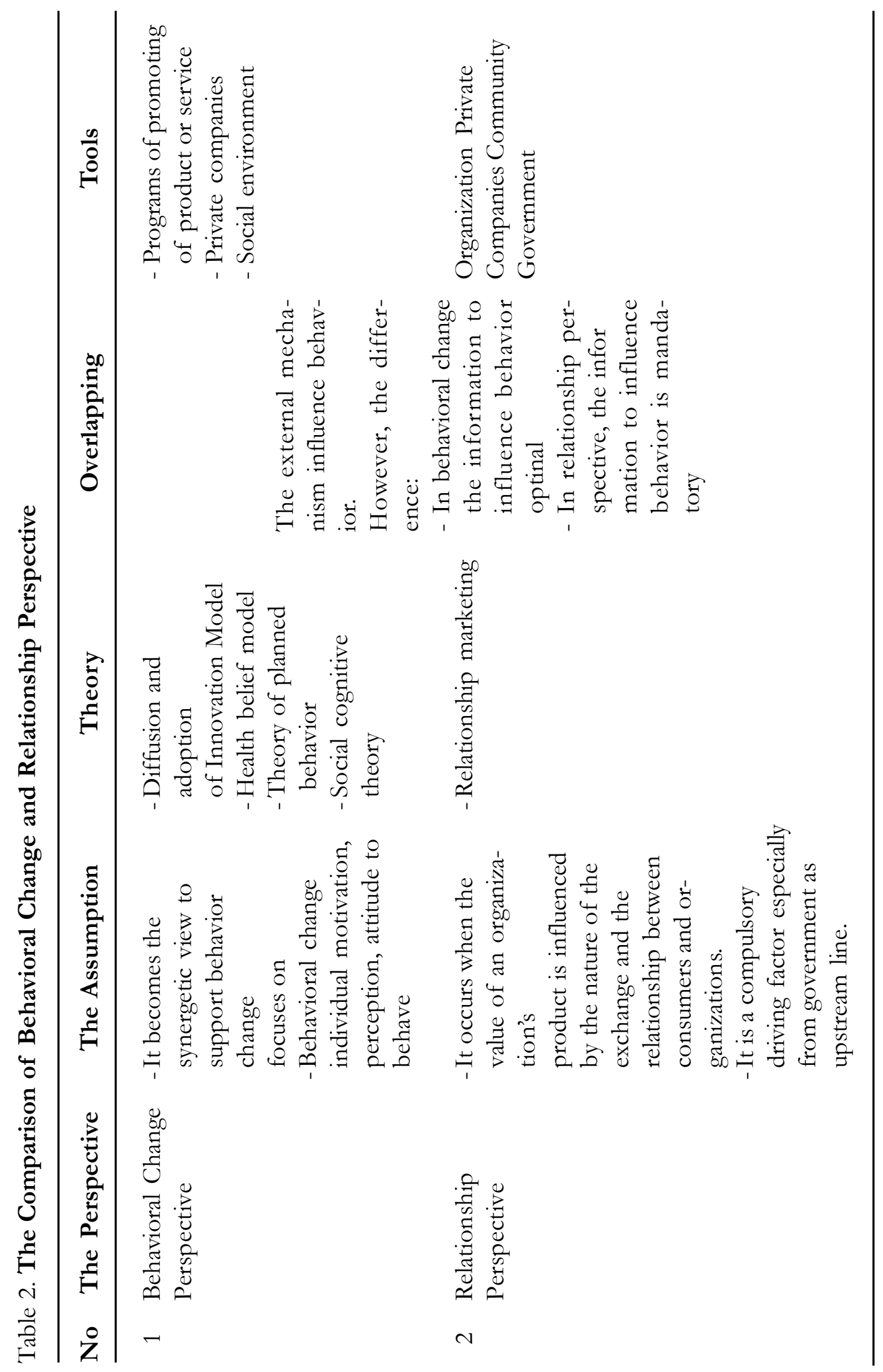


motion. The campaign, or another promotion tool, is not powerful enough to influence new behavior and does not directly influence consumers to change their behavior. It needs relationships with the community surrounding individuals. Community as a social environment can sustain good behavior. Community can carry out programs that sustain good living in society. Social marketing is not a matter of a social campaign to endorse good behavior because reminding and pursuing good behavior are not only related to the formation of new and better attitude instanly. It needs a stronger mechanism and a long process.

\section{The Perspectives}

Behavioral change and relationship perspectives are not competing views to analyze behavior change into good behavior for individuals themselves and for society. This perspective becomes the synergetic view to support behavior change. Behavioral change perspective focuses on individual motivations, perceptions, attitudes to behave in certain ways. The marketing social programs initiate influence from the individual side, so the driver to change is emphasized on the individual side. However, behavioral change also emphasizes the external factors that influence the behavior. The influence of environment, marketing programs, family, are external factor that can also influence behavior.

On the other side, the relationship perspective is considered as the motivating factor from externals. These external agents are compulsory agents to create the condition to influence behavior. The internal driving factor is not sufficient to influence, but it needs the strong force from external agents including community, social organizations, schools, private companies, and government. There is a compulsory need from individuals to join and to comply with the external agents. These external agents can shape attitude and behavior. Table 2 provides the comparison of these two perspectives.

\section{Behavioral Change Perspective}

Social marketing, like generic marketing, is not a theory in itself. It is more about a framework that draws from other bodies of knowledge including psychology, sociology, anthropology and communications theory to understand how to influence consumer behaviour (Kotler and Zaltman 1971). Like generic marketing, social marketing also discusses applying an exchange concept, consumer oriented research, segmentation, targeting to improve social individual welfare and society.

When applying the strategy to conducting social marketing programs, a decision maker is supposed to begin with studying the existing literature and research to gather information and to identify enablers and barriers to change behavior in a better manner. The information about social behavior concerns knowledge, belief, attitude, and motivation. The information might help to widen the understanding about behavior change (Lee and Kotler 2011). The theories of behavioral change are social norm theory, diffusion of innovation model, health belief model, ecological model, theory of reasoned action, theory of planned behavior, social cognitive theory, social learning, behavior economics, However, this study only limits the theories related to behavioral change to diffusion of innovations model, health belief model, theory of planned behavior, and social cognitive theory. The consideration is about practicality and those frequently used in the consumer behavior literature. 


\section{Diffusion and Adoption of Innovations Model}

Kotler and Roberto (1989) argued that the concept of diffusion can explain the adoption of new behavior by applying social marketing. Decision makers or social marketers have to plan the spread of adoption of new behavior by identifying both individual behavior and the mechanism by which new ideas and practices spread to the larger group. Diffusion is defined as a macro process concerned with the spread of new products or ideas among the public, meanwhile adoption is a micro process that focuses on stages in the acceptance or rejection of a new product or idea (Rogers 1995).

This concept can explain the adoption of new ideas about healthy behavior. In social marketing, the objective of the marketing of new ideas is to try to gain wide acceptance of the idea quickly. A social promoter realizes that the stages in the adoption process include awareness, interest, evaluation, trial and adoption. The first step to implement the social idea is to understand the awareness and interest of consumers. The difficult task for a social promoter is trying to change consumer's belief in the benefit of the idea adoption. The belief is difficult to change because consumers might perceive risk or uncertainty. Consumers who perceive no risk in adopting new idea are more likely to accept the idea. The level of education can be related to the idea adoption. There is no doubt that new ideas about creating a better life are particularly attractive to educated consumers. Furthermore, the new idea to be accepted is also influenced by the characteristics of the new idea. They are relative advantage, compatibility, complexity, trialability, and observability (Rogers 1995).
To facilitate the easiness of adopting new behavior, a social promoter uses a variety of communication channels for spreading the new idea. Furthermore, it needs opinion leaders or the community to support individual consumers, and for society to have awareness of social marketing programs. The steps of adoption of the research and the characteristics of the new idea must be recognized to implement better social marketing programs.

\section{Health Belief Model}

The health belief model has been commonly used in education and health promotion since Lefebvre (2000) argued that the health belief model, social cognitive theory, and theory of reasoned action, were the most frequently cited in explaining social marketing. The health behavior model has been analyzed based on previous research and literature review. The literature review showed that there are a communication model, social model, cognitive model, behavioral model, and marketing model. The health belief model is categorized as a cognitive model that emphasizes the health behavior's perceived benefits and barriers, the perceived threat of harm and perceived internal and external cues to actions as determinants (Moorman 1993, 2002). Perception involves perceived sustainability, perceived seriousness, and perceived benefits of taking action, perceived barriers of taking action and cues to action.

The health belief model provides the mechanism to increase healthful behavior by applying marketing techniques to deliver health message and to influence beliefs and attitudes. Social promoters can create messages about healthy behavior using the internet and direct mail. Social marketers have successfully promoted healthy behavior such 
as stopping smoking, taking more exercise, engaging in safe sex, engaging in physical activity, using transportation safety, skin cancer prevention, and reproductive health. Furthermore, health behavior can be supported by edutainment programs that reach an audience (Evans et al. 2008). Edutainment can be combined with knowledge and skill building through information about health. Education implies more than information provision. Education plays an important role in marketing plans including in the implementation of social marketing (Donovan 2011).

\section{Theory of Planned Behavior}

The theory of planned behavior represents more comprehensive integration of attitude components for better explanation of behavior prediction (Bagozzi 1992). Attitude toward behavior corresponds more closely to actual behavior. It is related to the belief of positive evaluation and consequence of doing so. In addition, to understand intention, there is subjective norm that influences a consumer to act. A subjective norm is relevant to the reference group, family, or work environment. The underlying subjective norms are normative belief and motivation to comply with social norms. This influence is related to the formation of intention. Another component is perceived behavioral control. It refers to an individual's perception of whether someone can perform intended behavior or not.

The theory of planned behavior contributes to social marketing implementation. The formation of a good attitude can be influenced by reference group and media. Reference groups, especially family and close friends, as the subjective norm can form attitudes that influence an individual's life (Howard and Gengler 2001). The most important is family because its role is providing children with basic values and norms. The communication marketing program transmits the information by attributing the message with the credible communicator (Kang and Herr 2006). This mechanism can be the form of transmitting health information to consumer and society.

\section{Social Cognitive Theory}

Social cognitive theory explains the reciprocal determinism about the behavior, cognitive factors, and environmental factors, including interpersonal factors (Lefebvre 2000). The individual consumer is affected by both by the internal and external factors. The behavior acquisition is related to the ability of someone to observe others. This observational learning can reinforce or punish behavior. Social cognitive theory can be applied to social marketing, for example, in education, and public health. Eventhough social marketing is not only about social advertising and promotion media outreach, corporations can use media to educate through health campaigns and to deliver messages about the consequences of, or punishment for, not following the message. The social cognitive theory can be applied to the intervention of behavior such as the implementation of policy, environmental change, school based intervention, direction action for community, and school curriculum based programs (Stead et al.2007).

Promotion tools must be integrated to enhance the effectiveness of social marketing. The promotion must be integrated because it can implement centralized communication, increase the chances of successful attitude change and have consistent messages. The message of all promotion tools must convey consistent messages about health behavior (Hawkins et al. 2011). Furthermore, the message must deliver information about 
the consequence or punishment related to not doing the behavior. When promoting a message, social marketing is not related to propaganda. Propaganda is relatively subjective and open to criticism and exaggeration. Social marketing has components that are fully educated in the marketing concept and more civic (O’Shaughnessy 1996).

\section{Relationship Perspective}

The relationship perspective is the argument that is initiated to focus on relationships, not on transactions (Gummesson 1997). A corporation has the perspective to build, to maintain, and to enhance customer relationships and has guidance to operate marketing activities by implementing the relationship aspect. Kotler and Keller (2012) argued that there is a change in company orientation toward the marketplace. It starts with the concept of product orientation, production concept, selling concept, marketing concept, and holistic concept. The holistic concept is about the development and implementation of a marketing program that has breadth and interdependency. The elements are internal marketing, integrated marketing, performance marketing, and relationship marketing.

Relationship marketing leaves the exchange theory that people will pay only as much as they think a product is well-evaluated. It relies on the most appropriate pricing for a product (Tian and Borges 2012). The concept of exchange is still relevant, however Negus (2002) argued that the concept must be added to welfare exchange. It occurs when the value of an organization's product is influenced by the nature of the exchange and the relationship between consumers and organizations. Furthermore, the welfare exchange concept must be based on intrinsic motivation, fairness \& voluntary social interaction between consumer and corporation. The implementation of relationship marketing can enhance consumer trust in a corporation (Choi et al. 2007). In applying relationship marketing, there must be a partnership. The partnership is not only intrapersonal (individual), interpersonal (family and friends), but also institutional, and at the community and public policy level. Therefore, the implementation of relationship perspective for understanding social marketing is about the cooperation with external organization, community partnership, and government networking.

\section{Community Based Social Marketing}

Social marketing is a medium to carry out communication programs that can influence consumer behavior. The behavioral change is considered difficult if it is focused directly on individual consumers. The Transtheoretical Model is considered to be intervention to change behavior (Proschaska and Velicer 1997). This model is a mechanism to integrate stages of readiness to perform intended behavior. The five stages of behavioral readiness are pre-contemplation (when an individual does not think there is a need to change); contemplation (when an individual has thought about the necessity to change); preparation (when an individual is going to try to change the behavior); action (an individual's behavior has occurred within months); and maintenance of behavior. The movement of each stage requires time to change. Sometimes, it is very difficult for social promoters to transform attitude change into behavior change. It needs intervention by doing community based social marketing. This intervention is expected to make con- 
sumers or society have commitment and increase participation in behavior change (Carrigan et al. 2011).

Through community based social marketing, a program of social marketing can be used to change consumer behavior and it draws the framework of social psychology. Community based social marketing tries to produce behavioral change via direct communication and community level initiatives. Dearing et al. (2006) argued that community, as the locus of change, can be the informal structure to support behavior change. Community based social marketing consists of four steps, namely: uncovering barriers to behavior; choosing selected behavior to promote; designing a program to overcome the barrier to the chosen behavior; piloting the program and evaluating the program (McKenzie-Mohr 2000). McKenzie-Mohr (1999) argued that community based social marketing focuses on grassroots engagement and provides practical guidelines for community activities.

A behavior change initiative is effective if it is delivered to the community using personal contact (Kennedy 2010). Communication is a tool to implement the program and to capture the target's attention. In addition, incentives and commitment are also the tools to motivate the behavior change. Wang and Katzev (1990) conducted community based social marketing for paper recycling in Oregon. In their research, four groups of residents were monitored. The first group signing a public commitment recycled for four weeks. The second group made a private commitment. The third group was given an incentive to recycle. The fourth group, as a control group, was given information leaflets. The first three groups showed more significant behavior in recycling than the control group.

\section{Upstream Line}

The emphasis on society as well as the individuals illustrates another aspect of social marketing. The change of individual behavior does not only come from individuals but also from organizations, and policy makers (Stead et al. 2007; Domegan 2008).

\section{Policy Makers}

Policy makers as the upstream line refers to macro environmental challenges that have implications for the strategy formulated by social marketers to influence consumer behavior (Niblet 2005). Policy here means the regulation or structural foundation to improve behavior. The collaboration between government, leaders, and licensing authorities is crucial. Marketing strategies have been considered as the weak influencefor behavior change. Policy makers should advocate environmental changes to evoke the positive attitude. Government is expected to protect citizens and to have concern for what is right and for future generations (Wymar 2011).

Purdue et al. (2003) argue that policy has impact on environment especially for creating a healthy environment for society. They are environmental regulation, zoning, building and housing, taxing power and spending power Social marketing is not only for promoting healthy behavior, but also sustaining healthy behavior in other aspects especially through a conducive environment. The increasing rate of pollution has the negative implications for the health of consumers. This is due to the increasing number of vehicles such as motor cycle and cars. Local government can give tax incentives to corporates to build sidewalks. Policy makers are supposed to provide social support and to advance active living. 
Smoking is also an important aspect that must be handled. Tobacco smoke contains dangerous substances. The smoke can endanger pregnant women and people in general because being exposed to the smoke can lead to disease. A smoking ban in public places in Indonesia has been implemented. The Governor Regulation No 75 Year 2005 of Smoking Ban in Public Places is considered as the effective tool to protect consumers and society from the danger of tobacco smoke. It is the mechanism to force people to compy with the rule.

\section{Organization}

Marketing activities are related to human behavior. They endeavor to craft marketing strategy to gain consumer attention, to win competition, and to add to corporate profitability. The consumer behavior becomes the interest point. However, a major consequence of consuming products is influential on consumer life (Andreasen 2003). Health problems such as obesity, cancer, morbidity, drug addiction, and shopping compulsively are seen as problems of human behavior.

The private sector can exploit and provide an opportunity to transfer technology services and to enhance society (Hasting and Saren 2003). The involvement of private sector is urgent because it can help the growing demand and expandable consumer choice. The private sector involves commercial entities, NGOs, and social organizations. This private sector must be supported by environment policy to involve it as a partner for planning, decision making, and evaluating the program. For example, in Indonesia, the organization of National Population and Family Planning Board has a commitment for organization of family planning by developing cooperation with private sector entities such as Astra Agro Lestari and Cahaya TV Indonesia (http://www.bkkbn.go.id).

The private sector can be a school because a school is one of the agents of socialization for sharing information for good behavior. Schools can also be the social and psychological factor for promoting the negative impact of drug use for example. According to past research, the school program can consist of three aspects psychological inoculation, normative education and resistance skill training (Botvin et al. 2001). This is an intervention by adopting a classroom curriculum.

Social marketing is done to change individual behavior and to enhance people's standard of living. Enhancing human living needs support from another network. This network is one of the relationship perspectives that can provide an active interaction and affect the quality of customers' lives. One of the networks is non-government organizations (NGO) or civil society organizations (Raval et al. 2007). NGO has a formal organization structure, non-profit entity, and has the resources and capability to manage. The role is to manage programs in the pursuit of public good.

Organizations here can also be private companies. Private companies can provide products or services for fulfilling customer's needs. Private companies can do social marketing and social marketing is related to commercial marketing. However, social marketing is not related to social responsibility marketing. Social responsibility marketing is related to applying marketing principles to protect the environment and community but at the end still focusing on profit purposes (Brenkert 2002). Social marketing aims at giving solutions for social problems not having a care for social problems by implicitly 
providing product or service of the corporation. Unilever in Indonesia for example is one of the corporations that pays great attention to social problems. Their marketing strategy is to campaign for supporting good and healthy behavior. Unilever delivers campaigns such as Rinso "Ayo Main, Jangan Takut Kotor;" Lifebuoy "Iawara Nggak Takut Jerawat;" Dove "Honesty, Simplicity, Diversity." These campaigns are not classified as social marketing because at the end of this campaign, consumers are eventually urged to consume the product.

\section{Lesson to learn}

Each perspective has illuminated the understanding of social marketing and each perspective can be applied to solve the problem. Ideally, when examining the social problems that are occurring, each perspective is inseparable. Any individual behavior is influenced by both external and internal factors. A corporation is expected not to have the assumption that individuals are responsible for their own good behavior. Good behavior in terms of the interaction of an individual is about that which is between the individual consumer and environment.

\section{Here is a case of a social marketing program.}

The study of Hawkins et al. (2011) showed the social marketing program in public school such as sun protection, immunization, dental care, smoking cessation campaign. This study utilized integrated marketing communication programs in developing social marketing programs such as sms messaging, toll-free numbers, web pages, e-mail, blogs, You Tube, Twitter, Facebook, event, publicity, and sales promotion techniques. Utilizing social marketing is supported by the Health Public School (HPS) that is developed by WHO to put into operation health promotion concepts that influence healthy behavior change and supported by New Zealand Ministry of Health. HPS framework focuses both on health issues and provides a model for school to tailor their own programs to address issues. The program is health promotion that has children orientation. The health programs are communicated to children as the customers with relevant messages. By communicating the programs, children as the students are involved in identifying health issues they perceive as important aspects. The social marketing programs promote and support healthy practices by using a variety of communication methods. Communication facilitates exchanges with children by sharing ideas and encouraging children to behave in a healthy way. The health concepts are incorporated in classroom learning and daily school life. There are the participating staff of HPS who become the enablers for teaching and learning. The participation also comes from community consultation, parents, and local community groups. There is two-way communication process and proactive in initiating health promotion activities.

The finding of the study shows that the behavioral change perspective and relationship perspective in social marketing programs are relevant. It supports theoretical literature with concrete evidence. One of the theories in behavioral change perspectives is social cognitive theory. Stead et al. (2007) argued that the intervention of social behavior can be supported by internal and external environments. This intervention with regard to the behavior is a school and community based intervention. The case of the HPS program supports the social cognitive theory. In addition, support for real behavior change must be provided by effective communication. This effective communication includes 
traditional and modern tools that are applicable to initiate the behavior. Social cognitive theory also underlines the role of external factors including promotion tools to influence behavior. The case of HPS shows that media communication has been successfully deployed including traditional and modern media.

The relationship perspective is also applicable for analyzing the case. Influencing individuals needs the cooperation of corporations, agents or other institutions. Negus (2002) argued that welfare exchange needs to be a voluntary social interaction between individuals and corporations. It needs the participation of the community and even the government. Community based social marketing in case of HPS is related to school. School can be the community as the medium to alter behavior. Individuals regularly have active interaction with the community. This intervention can support behavior change. The New Zealand Ministry of Health provides an effective means to improve children's health. Government acts as an upstream line to protect citizens and has concern for what is right and for future generations.

After reviewing a social marketing case from each perspective, both perspectives, behavioral change and relationships, can be useful to analyze it more comprehensively. The case of social marketing describes that the behavior change involves some levels of change. Domegan (2008) argued that social marketing programs include the change on five levels, namely: intrapersonal/individual; interpersonal (family and friends lend social support); institutional/organisational; community (local or regional social networks more distant from family and friends); and public policy. To promote behavior, the first level that must be focused on is the individual level. It tries actively to motivate good behavior from the individual's side. The previous case of public school shows that there is integrated marketing communication in social programs. This program tries to influence at the individual level. The next level to be concerned with here is the interpersonal level. In this case, the staff of HPS has a contribution to the influencing of the behavior. Both levels, individual and interpersonal, are the explanation of behavior change perspectives. Meanwhile, simultaneously, the levels of institution and of public policy, as the explanation of the relationship perspective, also play a role in influencing the behavior. The adoption of behavior change extends for a longer time, through adaptive learning, and requires all layers of society to promote a good behavior at the same time (Domegan 2008). Individuals are not considered to be responsibles for their own good behavior; it is instead the interaction between the individual and larger social and physical environment (Wymer 2011).

\section{Research Methods}

Is also important to discuss further the research process of the two perspectives. The research process involves following steps as Lee and Kotler (Lee and Kotler 2011) have identified out. Vazifehdust et al (2011) argued that social marketing research can use both qualitative and quantitative research performed to identify market segments that have the potential for intervention to promote good behavior, for developing and pretesting the acceptability of social exchange and evaluating the marketing campaign. Social marketing research is designed to understand the target audience's characteristics, attitudes, beliefs, values, behaviors, experience, needs, 
determinants, benefits and barriers to behavior change.

The implementation of behavior change and relationship perspectives can be analyzed by using quantitative and qualitative approaches. The following is a type of research to analyze both perspectives.

1. The research process can be descriptive because it is related to the planning process for promoting social programs and providing the explanation of information about programs outputs and outcomes. It can evaluate the social marketing programs. The evaluation can analyze the resources used for the campaign, activities of campaign, campaign visibility, changes in behavior as short-term outcomes, knowledge, beliefs, and improvement in social condition as long-term impact (Lee and Kotler 2011).

2. Formative research can be used to understand the target market by using primary data and secondary data. The intervention can be applied by using a quasi experimental design or survey. Experimentation research can be implemented to evaluate the effectiveness of a social marketing program. It helps a researcher make an inference about causality.

3. According to the qualitative approach, social marketing research also includes participatory action research or transformative consumer research. It tries to promote a research project that involves the objective of making someone's life secure or bringing about behavior change. The object of research is not the consumer; however there is collaboration with the researchers. Transformative consumer research deals with growing problems in society such as consumption, dangerous products, and compulsive buying (Ozanne and Saatcioglu 2008). This research is a new movement to create consumer life. The method assists researchers to understand the underlying problems. This mechanism can be supported by other agents or organizations such as government and corporations. Therefore, the result of the research can be beneficial for individual behavior and for society as well. This kind of research can be implemented to support the argument that social marketing involves multi-dimensional perspectives.

\section{Conclusion}

The explanation of each perspective promotes the understanding that social marketing concepts can be explained by a behavioral perspective and a relationship perspective. Ideally, social marketing programs can be implemented by considering the behavioral change perspective and the relationship perspective simultaneously. Each perspective provides an explanation of the theory including the practical matter of implementing the theory. The implementation of social marketing is supported also by ethical considerations (Brenkert 2002). Social marketing is about social or behavior change strategy to be targeted at those who care about changing. Social marketing is not just advertising, slogans or a campaign. The implementation needs integrated programs and support from many elements including downstream and upstream lines. Influencing change in behavior is very hard to do because it tries to change habituated behavior that is believed to be right. It needs a good coordination between the organizations involved. 
When implementing marketing activities, a corporation should take into account consumer welfare. Consumers are still allowed to buy products that fulfill their needs, but buying, consuming, and disposing of waste more responsibly. Marketing has to deal with the criticism of encouraging growth in consumption. Marketing can promote safe products, support healthy lifestyles and enter into cooperation with other organizations to provide a healthy environment. Marketing can use other social marketing techniques. Social marketing has to change attitudes, behavior, and maintain good behavior. When doing social marketing, the promoter should identify the target audiences because they different abilities in terms of awareness. Partnership with related organization can promote social marketing activities.

The principle of the Four Ps (product, price, place, and promotion), can be used to promote the behavior that enhances the qual- ity of consumer life (Lee and Kotler 2011). For product, this is the benefit for consumers if they perform the behavior, for example providing HIV testing services, counseling, mammograms, and children's education. For price, it is associated with the cost of adopting healthy behavior. The adopted behavior can provide monetary benefit and nonmonetary benefit. For place, it helps consumers to perform the behavior easily. It provides convenient access and reduces time related barriers including internet, transport, home delivery and mall. For communication, social marketing can communicate with customers by focusing messages on sustainability, for example driving the car less or reducing buying. Social promoters can consider using traditional communication (advertising, public relations, printed material, special promotion, signage, personal selling) and new media (social media, web sites) simultaneously.

\section{References}

Andreasen, A. R. 1994. Social marketing: Its definition and domain. Journal of Public Policy \& Marketing 13: 108-114

Andreasen, A. R. 1995. Marketing Social Change: Changing Behavior to Promote Health, Social, Development and the Environment. San Francisco: Jossey-Bass Publication.

Andreasen, A. R. 2002. Marketing social marketing in the social change marketplace. Journal of Public Policy and Marketing 21: 3-13.

Andreasen, A. R. 2003. The life trajectory of social marketing: Some implications. Marketing Theory 3: 293-303.

Bagozzi, R. P., F. D. Davis, and P. R. Warshaw. 1992. Development and test of a theory of technological learning and usage. Human Relations 45:659-686.

Blech, J. 2006. Inventing Disease and Pushing Pills: Pharmaceutical Companies and the Medicalisation of Normal Life. Routledge, Abingdon: Oxon.

Botvin, G. J., K. W. Griffin, T. Diaz, and M. Williams. 2001. Drug abuse prevention among minority adolescents: Post-test and one-year follow-up of a school-based preventive intervention. Prevention Science 2: 1-13.

Brenkert, G. G. 2002. Ethical challenges of social marketing. Journal of Public Policy 21:14-25. 
Carrigan, M., C. Moraes, and S. Leek. 2011. Fostering responsible communities: A community social marketing approach to sustainable living. Journal of Business Ethics 100:515-534.

Choi, C. J., T. I. Eldomiaty, and S. W. Kim. 2007. Consumer trust, social marketing, and ethics of welfare exchange. Journal of Business Ethics 74: 17-23.

Conrad, P. 2007. The Medicalization of Society: On the Transformation of Human Conditions into Treatable Disorders. The Johns Hopkins University Press, Baltimore, MD.

Dearing, J. W., E. W. Maibach, and D. B. Buller. 2006. A convergent diffusion and social marketing approach for disseminating proven approaches to physical activity promotion. American Journal of Preventative Medicine 31:S11-S23.

Domegan, C. 2007. The use of social marketing for science outreach activities Ireland. Irish Journal of Management 28: 103-125.

Domegan, C. 2008. Social marketing: implications for contemporary marketing practices classification scheme. Journal of Business and Industrial Marketing 23: 135-141.

Donovan, R. 2011. Social marketing's mythunderstanding social marketing. Journal of Social Marketing 1: 816.

Dosi, G., M. Faillo, and L. Marengo. 2008. Problem solving and governance in the cababilitybased view of the firm: The roles and the representations of organizational routines. In M. Becker Edwar Elgar (edt.), Handbook of Organizational Routines: 107-124. Cheltenham.

Gummesson, E. 1997. Relationship marketing as a paradigm shift: Some conclusions from the 30R approach. Management Decision 35: 267-272

Evans,W. D. 2008. Social marketing campaigns and children's media use. The Future of Children 18: 181203. Children and Electronic Media.

Hastings, G. 2003. Relational paradigms in social marketing. Journal of Macromarketing 23:6-15.

Hasting,G., and M. Saren. The critical contribution of social marketing. Marketing Theory 3: 305-322.

Hastings, G. B. 2007. Social Marketing: Why Should the Devil Have All the Best Tunes? London: ButterworthHeinemann.

Hastings, G., and K. Angus. 2011. When is social marketing not social marketing. Journal of Social Marketing 1: $45-53$.

Hawkins, J., S. Bulmer, and L. Eagle. 2011. Evidence of IMC in social marketing. Journal of Social Marketing 1:228-239.

Howard,D. J., and C. Gengler. 2001. Emotional contagion effects on product attitudes. Journal of Consumer Research 28:189-201.

Kang, Y. S., and P. M. Herr. 2006. Beauty and the beholder: Toward an integrative model of communication source effects. Journal of Consumer Research 33:123-130.

Kennedy, A. L. 2010. Using community-based social marketing techniques to enhance environmental regulation. Sustainability 2: 1138-1160.

Kotler, P., and G. Zaltman. 1971. Social marketing: An approach to planned social change. Journal of Marketing 35: 3-12.

Kotler P., and E. L. Roberto. 1989. Social Marketing:Strategies for Changing Public Behavior. New York: Free Press. 
Kotler, P., and K. L. Keller. 2012. Marketing Management (14 ${ }^{\text {th }}$ ed.) Boston: Pearson.

Lawther, S., and R. Lowry. 1995. Social marketing and behavior change among professionals. Social Marketing Quarterly I: 10-11.

Lawther S, G. B. Hastings, and R. Lowry. 1997. De-marketing: Putting Kotler and Levy's ideas into practice. Journal of Marketing Management 13: 315-325.

Lee, N. R., and P. Kotler. 2011.Social Marketing: Influencing Behaviors for Good. Los Angeles: Sage Publication.

Lefebvre, R. C. 2011. An integrative model for social marketing. Journal of Social Marketing 1: 54-72.

Lefebvre, R. C. 2000. Theories and Models In Social Marketing. In P. N. Bloom and G. T. Gundlach (Eds), Handbook of Marketing and Society. Newbury Park: Sage Publications.

MacFadyen, L., M. Stead, and G. Hastings. 1999. A Synopsis of Social Marketing.

McKenzie-Mohr, D., and W. Smith. 1999. Fostering Sustainable Behavior: An Introduction to Community-Based Social Marketing. Gabriola Island, BC, USA: New Society Publishers.

McKenzie-Mohr, D. 2000. Promoting sustainable behavior. An introduction to community based social marketing. Journal of Social Issues 56: 543-554.

McLaughlin, G. 2009. Six, Going on Sixteen. Rethinking Schools. Milwaukee, WI (available at: www.rethinkingschools.org/restrict).

Molnar, A. 2005. School Commercialism: From Democratic Ideal to Market Commodity. New York, NY: Taylor and Francis

Moorman, C., and E. Matulich. 1993. A model of consumers' preventive health behaviors: The role of health motivation and health ability. Journal of Consumer Research 20: 208-228.

Moorman, C. 2002. Consumer health under the scope. Journal of Consumer Research 29: 152-158.

O'Shaughnessy,N. 1996. Social propaganda and social marketing: A critical difference. European Journal of Marketing 30:62-75.

Negus, K. 2002. The work of cultural intermediaries and the enduring distance between production and consumption. Cultural Studies 16:501-515.

Ozanne, J. L., and B. Saatcioglu. 2008. Participatory action research. Journal of Consumer Research 35: 423439.

Prochaska, J. O., and W. F. Velicer/ 1997. The transtheoretical model of health behavior change. American Journal of Health Promotion 2: 38-48.

Purdue, W.C., L. A. Stone, and L. Gostin. 2003. The built environment and its relationship to the public's health: The legal framework. American Journal of Public Health 93:1390-1394.

Raval, D., B. Subramania, and B. Raval. 2007. Application of the relationship paradigm to social marketing. Competition Forum 5: 1-8.

Rogers, E. M. 1995. Diffusion of Innovations ( $4^{\text {th }}$ ed.). New York: Free Press.

Sirgy, M. J., and D-J. Lee. 2008. Well-being marketing: An ethical business philosophy for consumer goods firms. Journal of Business Ethics 77: 377-403.

Stead, M., G. Hasting, and L. McDermott. 2007. The meaning, effectiveness and future of social marketing. Obesity Review 8:189-193.

Stead, M., R. Gordon, and K. Angus. 2007. A systematic review of social marketing effectiveness. Health Education 107: 126-191. 
Tian, G., and L. Borges. 2012. The effectiveness of social marketing mix strategy: Towards an anthropological approach. International Journal of Business Anthropology 3: 102-113.

Vazifehdust, H., M. J. Taghipourian, and Z. Gharib. 2011. Social marketing green marketing: The extension of marketing concept. European Journal of Economics, Finance, and Administrative Science 41: 20-33.

Verplanken, B., and H. Aarts. 1999. Habit, attitude and planned behavior: Is habit an empty construct or an interesting case of goal-directed automaticity? European Review of Social Psychology 10: 101-134.

Wang, T. H., and R. D. Katzev. 1990. Group commitment and resource conservation: Two field experiments on promoting recycling. Journal Applied. Social Psychology 20: 265-275.

Wymer, W. 2011. Developing more effective social marketing strategies. Journal of Social Marketing 1: 1731.

\section{Other References:}

CGI Memo for President Carter-P\&G Health Sciences Institute. www. pghsi.com/Clinto_Global Initiative.

BKKBN perluas jaringan kerjasama mengembangkan program KB. August,1,2012. www.bkkbn.co.id. (Accessed Sunday, August 1, 2012). 